\title{
The Greatness of Nahj al-Balagha and the Words of Imam Ali from the Perspective of Modern Christian Figures
}

\author{
Seyyed Mahdi Keizoghani ${ }^{1, a}$, Asghar Moulavi Nafchi ${ }^{2, b^{*}}$ \\ 1,2 Hakim Sabzevari University, Iran, \\ aseyyed1221@yahoo.com, ba.moulavi.n@gmail.com
}

Keywords: Appraisal, Imam Ali, Nahj al-Balagha, Christian figures.

\begin{abstract}
After the words of the Holy Quran and Prophet Muhammad's tradition, the words of Imam Ali have in their own right bestowed upon mankind the finest and the most valuable social, political, and religious wisdom. Ever since a millennium when Sharif ar-Razi compiled Nahj alBalagha using his unique and meticulous selection of Imam Ali's speeches, letters, aphorisms, this invaluable book has deeply influenced many figures and luminaries among both Shia and Sunni Muslims and non-Muslims, all of whom have embraced and appraised it. In this article, the researchers look into the remarks of twenty one non-Muslim figures on the worth and merits of Nahj al-Balagha. Most of these Christian figures are contemporary Arab poets and thinkers: such individuals as Khalil Farahat, Rocks Bin Zayed Al Uzaizi, Joseph Hashim, and Nasri Salhab to name just a few; however, some orientalists and western thinkers are worth mentioning such as Nursisian and Henry Corbin.
\end{abstract}

\section{Introduction.}

The personality of Imam Ali had long oriented the studies, writing, analysis, and comments of various groups of scholars and thinkers. Meanwhile, everyone in proportion to their scientific and specialty have paid attention to parts of the personal traits and characteristics of this great Imam. Besides Muslims, especially Shiites, other faiths and religions have not been deprived of this hidden treasure, and everyone has tried to bring out gems from the depths of this boundless sea of knowledge and power, in order to benefit themselves and others from such divine blessings. According to Hafezian Baboli:

Nahj al-Balagha is an encyclopedia of Islamic culture, and after the words of the holy Quran and Prophet Muhammad's tradition, it is considered the widest recognized and accredited Islamic resource of such unique religious value, originating from divine essence as learnt by Imam Ali, and as such it is a unique rosary from which divine revelation's perfume and the sweet breeze of Prophet Muhammad's speeches can be intuited and perceived. This marvelous book includes exalted philosophies, luminous sermons, codes of divine conduct, a cultural-system, a grand plan for just government, and ideal-yet practical-guidelines for a historical and mystical practice [1, p. 11].

Moreover, the late Imam Khomeini has well stated that:

Man shall be honored to have Nahj al-Balagha after the holy Quran as the most important material and spiritual life guide and beacon, such a great script securing human deliverance and emancipation, endowed with such spiritual teachings and government guiding principles comprising the greatest means to human salvation, all which truly comes from an immaculate Imam." [2, p. 7]

One of the best methods to achieve acquaintance with the different features and characteristics of this noble book is contemplation in the resonating remarks of scientific and literary grandees and dignitaries especially when these luminaries belong to other religions and cultures:

It is better to know about the mysteries of the sweetheart from the words' of others. (Rumi) 
In the following, we will study the judgments and viewpoints of some non-Muslim thinkers and scholars from both Arab-Christian thinkers and scholars to orientalists on Nahj al-Balagha and Imam Ali's thoughts.

\section{The Supporting Figures.}

Khalil Farahat. Khalil Farahat is a Lebanese scholar, poet, and writer. His works include From the Deeps, New Studies in Literature, and African Odes. [3, p. 331]. Farahat has composed a beautiful epic on Imam Ali called In Ali's Altar testifying to the fact that Ali is a pioneer and leader in various sciences. Here, he states that scholars and thinkers are inspired by Imam Ali as a rich sources to their knowledge. Farahat has likened these scholars to little birds who quench their thirst at the fountain and spring of Imam Ali's knowledge and wisdom: "Their knowledge relies on your spring of wisdom, / No bird's beak can dry out this eternal-water" [4, p. 78]. Farahat has also introduced Imam Ali's words as a cutting blade which never goes blunt just like his sharp and cutting sword, Zolfeghar by saying: "Your words are like the sword whose blade never goes blunt, / They are as sharp and cutting as the mighty Zolfeghar" [4, p. 100]. Farahat thinks of Nahj alBalagha and the Holy Quran as "Two brothers who shall never part, in such correlation that makes the Holy Quran the source of all eloquence in his poetic expression" [4, p. 107]. Thus, though a Christian, without any prejudice, Farahat apparently announces that Nahj al-Balagha contains all the subject matter and education of the Bible: "In Nahj al-Balagha you may find the whole Bible, / It is such a wonderful spring of divine inspiration." [4, p. 108]

Hanna al-Fakhoury. Hanna al-Fakhoury was a Lebanese Melkite priest, philosopher and linguist. In his History of Arabic Literature, he writes on Nahj al-Balagha saying, "In Nahj alBalagha Imam Ali's genius is manifested: genius based on a profound wisdom rooted in comprehensive understanding; a genius from which the particular and exact in nothing is hidden; such a genius that delves into depths and presents pure, solid, and lucid views," and on the words and sermons of Imam Ali, al-Fakhoury says, "These words are the most truthful image of Imam Ali's spirit. These perfumed words contain the divine virtue that existed in his heart. Such virtue that originates from faith in God, wonder at divine perfection in creation, and an avoidance from unsteady joys." [5, p. 325]

Rocks Bin Zayed Al Uzaizi. Rocks Bin Zayed Al Uzaizi was an author and literary man from Jordan. He has authored valuable works. In 1996, he was established as the head of Jordanian Writers Association, and from 1986 onward, he was the representative of the International Association of Human Rights in Jordan. Al Uzaizi has written valuable books about the lifestyle and personality of Imam Ali, namely, Imam Ali: The Lion and Saint of Islam. This book has been translated to Persian, too. He has devoted a chapter to the words and sayings of Imam Ali, and he has brought a selection of them and called them, Immortal-Ideas. Al Uzaizi comments on Imam's words saying that certainly any educated person, writer, scholar, and Arabic orator is indebted to Imam Ali. If every person in the world owes to the Quran for its role in the formation of their rationality and thought, without doubt, every educated Arab person owes Nahj al-Balagha their firmness of the pen and writing. He says about Imam Ali's scholarly concepts and ideas on government: "Whoever wants to understand Arab societies and Arab rationality should certainly read Nahj al-Balagha, and whoever wants to understand the right way to rule in Arab lands, needs Nahj al-Balagha." [6, p. 209]

Abdul-Masih Antioch. Abdul-Masih Antioch is a Christian poet and journalist, who was born in Aleppo and was educated there. Later he joined Abdul Rahman Kawakebi's school. At first, he published Alshuzur magazine in Aleppo and then 'Umran magazine in Egypt [7, p. 766; 8, p. 297-298]. Antioch's works include The Epic of Ali or The Blessed Alavid Qasida, Custom Built on the Exploits of Noble Men, Sultan Husain's Trip in Riyadh Bahrain, The Oriental or Eastern Movement, and Constitution. [9, p. 5-6; Sheikhu; 10, p. 419; 11, p. 312]

Antioch has composed a great poem on Imam Ali and has depicted different events in Imam Ali's life. The poem is about the pronounced power of his expression. In Antioch view, Imam Ali is 
an eloquent Imam and teacher, the greatest person who has spoken and written in Arabic: "It seems as if both Arabic oratory and rhetoric have been created for him, / As if he reveals eloquence from mysterious nonbeing, / He dominates all eloquence known to man and narrated before him, / No celebration is left for Father Ben Sa'ida, / That great eloquent orator who many sermons has delivered" [9, p. 701]. Then, Antioch continues by saying: "Imam Ali's sermons fascinate reason and serve it with such a divine wine whose butler is pure of all sin: These sermons whenever read, fascinate reason, / A Halal charm that fills the reader's soul, / This Halal miracle is that rhythmic speech and eloquence, / That is ample challenge to the intellect of people, / A pure, divine wine whose cupbearer is pure of all sin, / These sermons are a pearl necklace, / Strung to adorn and fulfil divine law, / Grasp that law and the guiding pearls adorning it" [9, p. 701]. Antioch is so impressed with Ali's word that he says, "Were it not for the fear of God and piety, I would say that these words are verses of the Holy Quran, in which ideals of divine leadership and guidance are reflected" [9, p. 740]. Moreover, Antioch has, at the end of his work, versified a selection of short wisdom as found in Nahj al-Balagha.

Paul Salameh. Paul Salameh, a Christian poet, scholar, journalist of Lebanon, was an accomplished scholar, capable writer, great poet, and famous lecturer. During his life, he attracted the attention of contemporary poets, scholars, and religious and cultural-figures. His works include Imam Ali Imam and Hussain, 1946; Palestine and Sisters, 1947; Prince Bashir, .1947; Ghadir, 1948; Modern Eve, 1949; Injured Memoirs, 1950; Conflict in Existence, 1952; Life Story, 1961; Bread and Salt, 1966; With Christ, 1967; From My Balcony, 1967; Under the Oak, 1968; In This Timer, 1970. [12, p. 349-350; 13, p. 18-22]

One of Salameh's prominent works is Eid al-Ghadir, a poem of 3500 verses, which reveals the events of Islam as relating to Imam Ali. The poem begins by describing the Pre-Islamic Period, otherwise known as the Jahili or the Ignorance Period, and ends by describing the events of Karbala and the martyrdom of Imam Hussain. Salameh, in the introduction to al-Ghadir, speaks of Imam Ali's eloquence: "It's enough for a lecturer to stand on the slope of a mountain, / Lift his head up and then have verses flow, / For his tongue to get familiar with clear Arabic words, / Words whose rules Ali, the Father of Hassan, has revealed," thus at the end of that introduction, Salameh bows and explains: "In truth my words and expression bow down to you, / As my poem is a gravel to you, the Lord of Speech.” [14, p. 12.]

Salameh distinguishes Imam Ali as, the Lord of Speech and the Originator of Eloquence after Prophet Muhammad. In his opinion, Nahj al-Balagha and the words of Imam Ali are a vast ocean wherein souls commune and convene, such comprehensive words that sometimes become soft and gentle, so that the ear and heart avail the best and the most by their beauty, and sometimes Imam Ali's very own words become so strong and overwhelming and exciting as if a volcano has erupted. "After Prophet Muhammad, also known as Taha, / Ali is the righteous Lord of speech, his brother, his son in law, / He is like a sea in which souls and lives come together, Your words in elegances benefit the ear and heart as the echoes of appreciation exist in it, / He sends forceful words as flames, as from the depth of a volcano, / And, when he speaks with humility, / His gentle words are like such a charm, / That tolerance takes on disgrace in its soft, tender glow." [14, p. 184-185]

Paul Salameh in his article, Imam Ali: The Lord of Speech, refers to the words and rhetoric of Imam Ali. He bring some words of Imam Ali and comments on them and expresses his wonder. In his article, Salameh says, "I cannot think of any soul skilled at eloquence, who has not learned that given eloquence from a source other than the Holy Quran, the words of Prophet Muhammad or Imam Ali's. Those who have not been the direct students of Imam Ali, have surely learned from his students." [15, p. 19]

Henry Corbin. Henry Corbin was a philosopher, theologian and professor of Islamic Studies He is a German orientalist that has authored valuables work on mysticism and Sufism. Among his work are History of Islamic Philosophy; Iranian philosophy and Comprehensive Philosophy; Iranian Islam [16, p. 89-91]. Professor Henry Corbin writes: 
Nahj al-Balagha, after the Quran and Prophet Muhammad's tradition, has prime importance, not only as a general foundation for Shia religious life, but for the philosophical and intellectual tradition of the Shia. For this reason, we can consider Nahj al-Balagha as one of the most important sources of doctrine to have come under close attention as a basis of education by Shia scholars and thinkers, especially in the fourth period. The status and effect of this book relates to its doctrinal aspects aimed at setting logical relationships in the world, establishing a correct approach of arriving at conclusions, creating technical terms in Arabic: terms of such great beauty, literary and philosophical richness to have entered the Arabic language. All of these are independent from the Greek texts that have been translated to Arabic, and as such this book is the source of organization and a special form of Shi'a philosophy. The Shia have copied from this book all the content that are related to theology, for the words of Imam Ali form a complete philosophical system. [17, p. 18]

Amin bin Rashid Nakhla. Amin bin Rashid Nakhla is a Christian lawyer and poet who was born and educated in Beirut. He graduated from Damascus Law School. He was a journalist, lawyer, and a man of politics as well. His works include The New Diwan and The Books of Ghazals, A Books of Emergency Law, The Rustic Memoir, Under the Bond of Aristotle. [3, p. 408]

Professor Amin Nakhla writes about the sayings of Imam Ali in Nahj al-Balagha: "If everyone wants to cure their souls of disease, / They should learn Nahj al-Balagha and tread under its light" [17, p. 18]. Nakhla's answer to a person who asks him a few words about Imam Ali to gather and publish in a book:

You have asked me to choose 100 speeches of the most eloquent person among Arabs, that is, Imam Ali, the Father of Imam Hassan, for you to publish in a book. I do not have access to such a collection, but the only source I can introduce is the Holy Bible of Arabic rhetoric called Nahj al-Balagha. I have thumbed this book with great pleasure, by God. I don't know how to choose from among the words of Imam Ali only 100. I do not know how to detach one word from another, it is like picking up a precious ruby grain sitting next to another equally priceless grain. I finally did that, while my hand shook back and forth with the bright rubies dazzling my eyes with such staring divine and heavenly light. It is surly unbelievable, for the astonishment and confusion I had to endure for attempting to single out words from the spring and fountain of rhetoric. Verily, the gift and bounty that Allah has bestowed on Arabic literature and Arab societies is far more than these 100 words. [18, p. 39-40]

Mohammed bin Nael Hassan El Marsafy. Mohammad bin Nael El Marsafy was raised in Cairo and educated in al-Azhar and Darul 'Ulum. In Freire School he was appointed as teacher and he published Al-Jadid and Shahrezad magazines. His works include Innovation in Dictation, Pearls in Composition, and Literature in Arabic [8, p. 234]. El Marsafy, a venerated professor of Egyptian literature, describes Nahj al-Balagha:

God has appointed Nahj al-Balagha as a clear evidence that Imam Ali is the best sample of the sparkling light, wisdom, guidance, miracle and eloquence of the Holy Quran. In Nahj al-Balagha, Imam Ali possesses such signs of full wisdom, evidence of correct policy, clear advice, and expressive reason that great sages and foreign philosophers don't embrace. Herein, Imam Ali has traversed and absorbed the depths of science, politics, and religion, and in all these realms he is an accomplished genius. [19, p. 291]

Ibrahim al-Yaziji. Ibrahim al-Yaziji was an Arab philologist, critic, poet, and journalist. He belonged to the Greek Catholic population of the Mutasarrifate of Mount Lebanon. Yaziji's family is originally from Homs and it moved before he was born in Beirut. His works include The Necklace: A Book of Verse; Fine Examples of High Oratory, and Naj'at al-Rai'd [5, p. 1058]. Abdul Masih Antioch refers to the words of al-Yaziji, as a great writer and linguist of the $20^{\text {th }}$ century, on Nahj al-Balagha: 
I was not well-versed in Arabic writing, I came near maturity and satisfaction only after I had studied the Holy Quran and Nahj al-Balagha, what students should recognize and cherish as two eternal treasures and resources that never expire. It's impossible for a student to be skilled and proficient in style without burning many a midnight oil to study these two invaluable sources, a secure and sure response to the demands of any inquirer. [9, p. 700]

Suleiman al-Katani. Suleiman al-Katani is a Lebanese contemporary writer. His works include "Prophet Muhammad, Imam Ali, Fatemeh Az-Zahra, Imam Hassan, Gibran Khalil Gibran" [20, p. 193]. Al-Katani's work, Imam Ali, has been recognized as a distinguished book by the religious authorities and scholars of Najaf Seminary. Here, al-Katani refers to Nahj al-Balagha by saying that:

This book has been authored by such a mighty pen that is right in form and worthy in content. Its style reflects a fitting garment of stature and originality in meaning, for in rhetoric and power of meaning, this text is actually landing a great meaning in an upright and stable form. [21, p. 214]

Sobhi Saleh. Sobhi Saleh is a contemporary researcher and scholar of Lebanon. He has a valuable work in the field of Arabic language and literature. He has published Nahj al-Balagha along with his research and description. In the introduction, by citing examples of Imam Ali's speeches in different topics, he expresses his wonder and admiration at Nahj al-Balagha. He writes about the progressive wisdom of Nahj al-Balagha:

If we put aside the sermons and letters of Imam Ali and go on to selections of his wisdom, we realize that the miraculous and convincing sense of Imam Ali, reveals vast knowledge, right experience, and deep understanding of reality and truth. [22, p. 15]

He speaks of the structure of Imam Ali's arguments and the value of the Holy Quran and Prophet Muhammad's tradition:

Undoubtedly Quranic wisdom and tradition have helped him with an eternal spring and fountain of truth. He structures his speeches and letters around the vivid visual style of the Holy Quran and the multiplicity of form and content in words and compounds derived from the Holy Quran and the Prophetic tradition. [22, p. 16]

George Jordac. George Jordac was a Christian author and poet from Lebanon. He published a book about Imam Ali entitled The Voice of Human Justice. Jordac was born in 1931 from an Orthodox Christian family. As a child, he read Nahj al-Balagha. He learned about Nahj al-Balagha from his brother Fouad Jordac, an engineer, philologist, and poet. When he was 13 years old, George had memorized much of Nahj al-Balagha.

Jordac's Imam Ali, The Voice of Human Justice is in five volumes: Imam Ali and Human Rights, Imam Ali and the French Revolution, Imam Ali and Socrates, Imam Ali and His Time, Imam Ali and the Arabs. Jordac, this renowned Christian Lebanese thinker and author, profoundly loved the character and ideas of Imam Ali. Mr. Jordac dedicated four decades of his life to study on a man whom he calls one of the greatest figures in the history of humankind, Imam Ali. Jordac earlier in an interview says that he hopes the next generations would ponder on the treasures that lie in the rhetoric of great men especially Imam Ali. George Jordac further says that he has always believed that the status of Imam Ali is above the historical or political-frameworks. In Jordac's view, if the world's intellectuals and authors just study Nahj al-Balagha and understand its concepts, masterpieces will be fashioned about him, but the Arabic and Islamic world have restricted the study of his character, a character which Jordac believes is that of a great reformist leader. But Imam Ali's valiance and great intelligence has left a profound impact on all terms in Nahj al-Balagha in the good sense of a live, strong, broad, and deep intelligence that is open to all serious and deep contemplation. Ali's scope of thought and expression is so vast and boundless that it leaves little space for 
negligence and disregard. Imam Ali has plunged in the deepest humanitarian matters and has turned upside down the most complex principles and in the field of speech has displayed and received the most hidden mysteries thus delving into the depth of life mysteries and secrets. Based on this rare and unique Alavid privilege, a logical consistency is evident in Imam Ali's words and hence articulates the unified and natural result of the chain of cause and effect as in perception and expression, for the Imam's thoughts have tied one argument to another both in form and content, and there exists an organic unity and cohesion in the totality of his works. Thus each and every term in Imam Ali's thought and speech opens new horizons that are windows wide open unto many a horizon beyond. [23, p. 142-144]

Nursisian. Allameh al-Shahrestani in his valuable book, On Nahj al-Balagha, writes:

In 1907, Nursisian, chief of British secretaries in the Consulate in Baghdad, who was an accomplished man, while talking to him spoke and expressed his opinion saying that Nahj al-Balagha is superior to any other principally human word in Arabic, because it presents the most intricate, delicate concepts and rhyming words of prose with little artificiality, something only to be witnessed in this book. Then, to establish his theory, he cites examples. The following lines are from Imam Ali's sermon on the creation of man in 'Nahj al-Balagha, namely, Sermon 83: Don't I describe to you how God created this creation? God in the darkness of the womb and the interior of veils and curtains, created man from spilled semen, and a insignificant blood clot, then the infant came, and it was weaned, then reached maturity. Then man was given a bearing heart, a speaking tongue, a perceiving eye. Nursisian read the words and was surprised at the greatness of the rhymes and refrains that like water flow in Imam Ali's words. He said if today this great speaker were on the pulpit in Kufa, you Muslims would verily see that the Mosque of Kufa with all its vastness would be crowded by a full community of western people who had come to plunge in the roaring seas of Imam Ali's thoughts and words. [18, p. 42-43]

Mr. Krnykoy. Allameh al-Shahrestani, in the book Ultimate Purification, in the second part, draws on the words of western scientists to bear witness to the all-encompassing majesty of the Quran and speaks of Mr. Krnykoy, an English literature professor at the Indian university of Aligarh, as a mentor and a speech master and scholar present in the house, whom upon being asked about the miracle of the Quran had said,

Nahj al-Balagha is the junior brother of the Holy Quran, wondering whether it were possible for anyone to bring the like of this junior brother which brings us the unique opportunity to wisely ponder its senior brother, the Holy Quran. [18, p. 16]

Raymond Qasis. Raymond Qasis is a contemporary Lebanese Christian poet. Qasis retains a background of enthusiasm for composing poems on Muslim Imams. One of these writings is a book on the appraisal of Imam Ali and Nahj al-Balagha, which is the compilation of Imam Ali's speeches, advices, and letters, and a Shia reference book. His works include The Story of the Goddess, A Poet's Papers, Imam Ali: The Wise Jurist and Knight, and Imam Hussain's Convoy. In his long poem, Imam Ali: The Wise Jurist and Knight, Qasis appraised and described various aspects of Imam Ali's accomplishments and personality. He says, "Nahj al-Balagha is the brightest beacon that gives light to any aspiring poet;" Qasis further notes, "Nahj al-Balagha is full of innovation and novel content and that Imam Ali's word is beyond the word of Sohban bin Vael, the famous pre-Islamic Arabic man of eloquent," and one of the issues that attracts the attention of Qasis is Imam Ali's letter to Malik. He says, "Although all the letters fascinate me, but this one is exceptional. I believe that this letter communicates divine law as if fragrant musk and basil were running on Imam Ali's truth-speaking tongue," as he believes "If present and future men of power and influence follow the guidelines of this illuminating letter as an operational action plan, no soul would ever have to witness all the calamity afflicting mankind." [24, p. 56] 
Joseph Hashim. Joseph Hashim is a poet, scholar, and former minister of Lebanon, who was engaged in journalism and teaching. Hashim's poetry includes A Stone on Rocks, Light from Light, The Good Breeze. His other works include The Voice of Lebanon in the Two Year War, Al-Farabi, Suleiman al-Bustani and the Iliad [7, p. 296].

He wrote a lot of poems about Ahl al-Bayt, and he spoke in various articles and books about the Shia and specially Nahj al-Balagha. He remarks:

Whoever studies Nahj al-Balagha and studies it, they will see the signs of Allah as this book contains and displays all the necessities of connecting heaven and earth, all ties and relations required to create a bond between a servant and their creator, and all instruments needed for the perfection of mankind. The general theme of this book is not directed at a specific religion, but it is a comprehensive work that addresses all men while speaking with them. Thus, Nahj al-Balagha can be used as a common book on interfaith dialogue between Islam and Christianity for the presence of such concepts in it as God, creation, this world, the hereafter, man, heaven, hell, and virtue all as absolute concepts without any narrow religious identity. [25, p. 103]

Joseph has written numerous poems to appraise and describe Imam Ali, in one of these poems he writes:

The sayings and words of Imam Ali are a fragrance of his mind, / And his sermons are illustrative of his thoughtful essence, / He refers to divine virtues and commands, / All in the most appealing literary form and sense, / All other books should ask for sense and knowledge, / And curing rain from his guidance light. (http://poets.setayeshgar.ir/)

Fouad Afram al-Bustani. Professor Fouad Afram is a literary scholar, historian of Arabic civilization and literature, and an archaeologist. Al-Bustani was editor of the Arabic Encyclopedia (six volumes, 1956-66). He was the founder and first president and rector of the National-University of Lebanon (until 1971). Al-Bustani's works include The History of Education in Lebanon 100 Years Ago and With Gibran Khalil Gibran. He has reviewed the style of Ali's words and cited some example of them in the first volume of Al-Raw'i'i. He knows Nahj al-Balagha as the peak of Arabic rhetoric and says that:

Imam Ali delivered sermons during the tumultuous events of his life and preached and wrote letters, and these are all a remarkable collection of wisdom, advice, rules, sermons, and prayers. Ali's letters display deep thought, precise measurement, and eloquence in expression. Nahj al-Balagha stands at the peak of Arabic writing. Sharif ar-Razi has rightly called it Nahj al-Balagha. [26, p. 296]

Antoine Bara. Antoine Bara, in his book called al-Hussain in Christian Thought, compares each of Imam Ali and Mu'awiya's words to their own children. He speaks of the valuable moral and educating will and advice of Imam Ali to Imam Hussain, Seyyed al-Shohada, saying that:

This will contains all the moral, social, and religious principles of life as a guidance for Imam Hussain to head and steadily advance toward the right path thus aiding the oppressed. How can one ever compare this blessed will to the words of $\mathrm{Mu}$ 'awiya's to his son, Yazid? [27, p. 151]

Raji Anwar Haifa. Raji Anwar Haifa is a Lebanese contemporary writer who has written several books and articles about Ahl al-Bayt. The most important of his works is Imam Ali in Contemporary Christian Thought, The Tragedy of Karbala in Modern World Conscience. It is worth noting that the book met great welcome and won a Gold Award from Ahl al-Bayt Foundation for Cultural Revival Institute. In the first book, Haifa has devoted a chapter to Imam Ali's linguistic knowledge and his rhetorical genius where he says that:

Nahj al-Balagha is a mirror of linguistic knowledge and the holy Quran, the attainment of whose high eloquence, rhetoric and content is beyond the reach of other scholars and 
speakers. Many Christian thinkers and writers know it as an immortal book unreproducible by other men of knowledge, speech, and rhetoric. [28, p. 550]

Nasri Salhab. Nasri Salhab is another contemporary Christian thinker and scholar of the Arab world. His numerous works include In the Footsteps of Christ, In the Footsteps of Muhammad, and In the Footsteps of Imam Ali. This Christian thinker refers to the eloquence and linguistic authority of Imam Ali. He believes that:

Imam Ali has achieved this linguistic knowledge and rhetorical genius in two ways: first through interrelating his holy spirited words and letters with the unique expression of the Holy Quran as revealed in this divine script, and second through Prophet Mohammad. [28, p. 557-558]

According to professor Salhab:

As each craftsman is represented by their art and each scientist is marked by their science, the collected sermons and speeches in Nahj al-Balagha clearly show that Imam Ali is the spiritual father of rhetoricians in the Arabic Language. [28, p. 558]

He writes about the Motaqin or Pious sermon and its spiritual and eloquent language stating that:

If anyone who reads this sermon wants to choose its most beautiful and highest peaks, they would be left in astonishment and after a while they would have to adopt all of it. Thus he would recommend all Christian believers turn to Nahj al-Balagha and read it carefully. [25, p. 100-101]

Lewis Ma'luf. Lewis Ma'luf is a contemporary Lebanese writer and linguist. $\mathrm{He}$ achieved widespread fame, due to writing the famous al-Monjid dictionary. He, in al-Monjid, refers to Nahj al-Balagha, as a collection of Imam Ali's word, and says, "Imam Ali is the founder of the first school of Islam from which extensive cultural, high currents and tides flow." [29, p. 378]

\section{The Doubtful Figures}

Besides these appraisals, there are also those random doubts and criticisms posed by a number of orientalists targeting Nahj al-Balagha, mainly rebutted by many scholars. Here, the researchers do not intend to delve into that line of controversy. However, the need is felt to make a reference to a least two instances.

Doubt over the Authorial Originality of Nahj al-Balagha. There are those who have been doubtful as to whether Nahj al-Balagha belonged to Imam Ali or not, Reynolds Nicholson is one such figure. "Nicholson is an English orientalists. He studied Greek literature and Islamic civilization and literature. He authored valuable books on Islamic civilization and culture, Persian literature, mysticism, Sufism, and Arabic literature. His works include a revision of Masnavi Ma'navi, and a versified English translation of 'Iraqi's Book of Lovers, and a history of Arabic literature" [30, p. 4434]. Nicholson states that Imam Ali had been skilful in verse and eloquence, and his verses and speeches had been recognized by Muslims; however, very few of them could be held his own. [31]

In response to these statements, it should be said that what Nicholson has said about Imam Ali's verse is partly true, because a number of those verses have been attributed to him. However, as far as Imam Ali's rhetorical and eloquent speeches are concerned, Nicholson is not accurate, because several books and articles prove the authenticity of Nahj al-Balagha and the accuracy of its authorial attribution to Imam Ali. These documents have made reference to the many resources that have cited Imam Ali's words and speeches before they were even compiled by Sharif ar-Razi, and a notable piece is Imam Ali's Shiqshaqia Sermon. [32, p. 37-40]

Among other scholars who have investigated the authenticity and accurate attribution of Nahj al-Balagha to Imam Ali, one can refer to Seyyed 'Abd al-Zahra al-Hussaini. 
Doubt over the Use of Scientific Terminology in Nahj al-Balagha. Doubt over the use of scientific terminology in Nahj al-Balagha is another issue raised by orientalists and modernists. It is claimed, "The scientific, philosophical, and sociological concepts and terms mentioned in Nahj alBalagha have not been prevalent in Imam Ali's age" [1, p. 61]. Hafezian Baboli responds by saying,

In this regard, it should be said that these orientalists are not familiar with the Holy Quran and the Prophetic tradition(s). They are unaware of the relationship between Imam Ali and Prophet Muhammad. These people display want information over this impeccable Imam's knowledge. Being an extraordinary figure, Imam Ali surprisingly mentions ideas and subjects that are unprecedented and unparalleled in Arab history and civilization. Thus, one should ask whether Arabs had prior knowledge of the all the wonderful Quranic knowledge revealed to the Holy Prophet. A similar legitimate inquiry would be if Arabs at that age were informed and knowledgeable about all matters relating to monotheism, theism, Allah's names and epithets, the history of past prophets and messenger, the history of other nations and peoples, the true account of the day of judgment or the true description of paradise or hell, and intricate moral and social issues. [1, p. 69]

Of course, such doubts have been answered in a more detailed manner, and one can consult other works by, namely, "Hadi Kashif al-Ghata who has studied the originality of Nahj al-Balagha and has rebutted such claims; or Muhammad Hussain Hussaini Jalali who has investigated the authenticity of Imam Ali's words and speeches." [1, p. 52-75]

\section{Conclusion.}

This article dealt with the comments of contemporary non-Muslim scholars, namely Christian and western, about Nahj al-Balagha. On the one hand, we can allocate this positive attraction and feedback to the lucid yet intricate style and the beautiful and stable structure of Imam Ali's words. On the other hand, it is Imam Ali's profound and hair splitting wisdom which addresses the most important political, social, cultural, and philosophical-issues that has triggered the wonder of these scholars and has led them to remember Imam Ali with great respect and sometimes enamored tribute. These intellectuals have discovered such valuable teachings that would not only impress the mind but also set right the heart of any man regardless of their faith or walk of life, realizing that Imam Ali speaks only of such human traits and properties that are the essential perquisites and characteristics of a divine and humane experience that aspires for the realization of virtuosity, represented by such moral values and qualities as forbearance, nobility, courage, loyalty, true faith, secrecy, modesty, kindness, forgiveness even toward ones enemies, moderation, consultation, learning from history, among many others. The private and social life of Imam Ali is a spotless mark of his firm belief in and practical adherence to these human codes and norms. Such a charismatic man of thought and action proves beyond resistance for both friends and foes.

\section{References}

[1] A. Hafezian Baboli, Nahj al-Balagha in Imam Ali Encyclopedia, Ali Akbar Rashad, Supervisor, volume 12, Tehran, Islamic Thought and culture Research Publications, 2006.

[2] R. Khomeini, The divine political will, Tehran, Institute for Compilation and Publication of Imam Khomeini Works, 1999.

[3] K. S. Al-Jubouri, Dictionary of men of letters from the pre-Islamic period to 2002, Beirut, Daralkitab al-'ilmiyah, 2003.

[4] K. Farahat, In Imam Ali’s Altar, Beirut, Zehlat Alfata, 1991.

[5] H. Al-Fakhoury, The history of Arabic literature, Tehran, Tus, 2001.

[6] R. B. Z. Al Uzaizi, Imam Ali: The lion and saint of Islam, Beirut, Dar al-Kitab al-'Arabi, 1979. 
[7] E. B. Yaghoub, Book of poets from the Age of an-Nahda, volume 2, Beirut, Dar al-Sadir, 2004.

[8] K. D. Alzarkly, Who’s Who?, seventh ed., Beirut, Dar al-‘Alam Lilmalayyn, 1980.

[9] A. M. Antioch, Imam Ali’s Epic, Beirut, al-‘Alamy Publishing House, 1991.

[10] L. Sheikhu, The history of Arabic language and literature, Beirut, Dar al-Mashriq, 1991.

[11] U. R. Kahalah, Dictionary of authors, Beirut, Dar 'Ihya' al-Turath al-'Arabi, 1957.

[12] Y. A. Dagher, Resources on literary studies, Beirut, 1983.

[13] M. Eid, Paul Salameh: The poet of epics and pain. Beirut, Dar al-Mashriq, 1992.

[14] P. Salameh, Eid al-Ghadir, Beirut, Dar al-’Andulus, 1961.

[15] P. Salameh, The history of Islam, Beirut, Dar al-Komail, Dar al-'awliya, 1987.

[16] M. Hosseini Tabatabaei, Critique of orientalists' works, Tehran, Cha Publications, 1996.

[17] M. Delshad Tehrani, Knowing Nahj al-Balagha, Golestan of the Quran Journals, 96, 14-21, 2001.

[18] S. H. D. Al-Shahrestani, On Nahj al-Balagha, A. Mirzadeh Ahari Trans., Qom, Islamic Publications Office, 1999.

[19] H. Abdullahi, Alavid virtues in the words of others, Sabzevar, Ibn-e-Yamin, 2002.

[20] Interview with Suleiman al-Katani, Mofid Letter, 7, 193-202, 1996.

[21] S. Al-Katani, Imam Ali: A beacon and fortress, J. D. Farsi, Trans., Tehran, Borhan Publications, 1992.

[22] Nahj al-Balagha, S. Saleh, Comment., Tehran, Offset Print, 1974.

[23] G. Jordac, The wonders of eloquence, Fakhr al-Din Hijazi, Trans., Tehran, Be‘sat, 2005.

[24] R. Qasis, Imam Ali: The wise jurist and knight, Zahlah, Dar al-Na‘im, 1979

[25] M. R. Zaeri, Father, Son, and Holy Spirit, Tehran, Kheimeh, 2010.

[26] F. A. Al-Bustani, Modern dictionary, second ed., Qom, Zovi al-Ghorba, 2002.

[27] A. Bara, Al-Hussain in Christian thought, Beirut, Darul 'Ulum, 2009.

[28] R. A. Haifa, Imam Ali in contemporary Christian thought, Beirut, Dar al-'Ulum, 2010.

[29] L. Ma‘luf, Who's who? Beirut, Dar al-Mashriq, 1996.

[30] A. H. Saeedian, The modern encyclopedia, Tehran, Elm va Zendegi Publications, 2001.

[31] R. Nicholson, History of Arabic literature, Keyvandokht Keyvani, Trans., Tehran, Vistar, 2001.

[32] I. A. K. 'Arshi, Nahj al-Balagha's authenticity, Seyyed Mortaza Ayatollahzadeh Shirazi, Trans., Tehran, Amir Kabir, 1984. 